\title{
SHEEP AND GOAT PRODUCTION CHARACTERIZATION UNDER MIXED FARMING SYSTEM IN THE DESERT COAST OF NORTH WEST - EGYPT
}

\author{
M.M.I. El-Ashmawy, M.A. Khalil, M.A. El-Wardany and S. Afify \\ Animal Production Research Institute, Agricultural Research Center, Ministry of \\ Agriculture, Dokki, Giza, Egypt
}

\section{SUMMARY}

Small ruminants are an integral part of mixed-farming systems in Egypt. Assessment of the existing small ruminant production systems is an important tool to inform researchers about producer problems and the opportunities available to improve on the prevailing systems. A structured questionnaire was used to collect data on milking animals, milk production, some reproductive parameters, most common diseases, animals marketing and cropping pattern. A survey was conducted from December 2008 to April 2009 in the Northwest of Egypt. Four districts were randomly selected out of seven (Matruh, El-Nigila, Sidi-Barani and El-Dabaa). In total, 99 Producer who practice mixed farming system were randomly selected and divided into four groups according to flock/herd size holdings of sheep and goat; $\leq 100,>100-\leq 200,>200-\leq 300$ and $>300$ heads.

Average daily milk production was 0.39, 0.42, 0.35 and 0.34 litter/ewes/day and $0.43,0.48,0.43$ and 0.48 litter/does/day for the four sizes respectively. Average lactation length for ewes was 83.4, 87.0, 81.9 and 81.1 days and for does were 108.9, 108.9, 111.9 and 83.7 days, respectively. Average parturition interval was 10.18, 10.04, 9.67 and 10.54 months for ewes and 9.67, 10.20, 10.06 and 10.08 months for does, respectively. Average age at first lambing/kidding was 17.8, 16.9, 17.3 and 16.6 months for ewes and 16.6, 16.7, 16.7 and 16.7 months for does in the four groups. Average cultivated areas owned by the producer in the four flock sizes were 85.8, 100.0, 120.0 and 164.1 feddan, respectively. Average age of selling animals was 23 and 21 months at an average body weight of 35 and $23 \mathrm{~kg}$ for sheep and goat, respectively. The most common diseases were pulmonary pneumonia, internal and external parasites, fasciolasis, trace elements deficiency and pseudo tuberculosis.

It can be concluded that the farming systems of the studied region are managed under a traditional system which is characterized by deficient facilities and generally high variability in managing practices and productivity. This study has produced a general understanding of the small ruminant systems and identified major challenges.

Keywords: Flock size, milk, market, diseases, mixed-farming systems, small ruminants

\section{INTRODUCTION}

Livestock production is an important agricultural activity in most of the regions in the country. The production strategy followed in an area, in general, depends

Issued by The Egyptian Society of Animal Production 
primarily on the climate and level of management. As far as the environment is concerned, livestock production is often practiced under unstable and hazardous conditions.

The important role of sheep and goats in traditional areas is well documented (Devendra et al., 1970, Wilson, 1988a and 1989b). Sheep and goats, like cattle, have played an important role in the livelihood of rural people in North Western Egypt. Indigenous sheep and goats are more common in the communal areas than the improved ones which are mostly found in the commercially owned farms.

Sheep and goats play an important socioeconomic role in supporting rural life especially for genders that are among the poorest farmers in Egypt. They are prolific and require low inputs for a moderate level of production, reach maturity early and are profitable to keep (Devendra and Burns, 1983).

Although there is now a sizable amount of published research on indigenous small ruminants in Egypt, most of the work published was carried out under controlled conditions at research stations and the results may not reflect the actual situation of small holding production systems prevailing in rural areas. Thus it is necessary to study the performance and limitations of these systems in existing rural conditions in order to recommend strategies for their improvement.

The main objectives of this paper were to characterize sheep and goat productive and reproductive parameters under mixed farming system in North Western Egypt and to identify the main sheep and goat diseases and their treatments.

\section{MATERIALS AND METHODS}

This study was conducted in the coastal area of North Western Egypt (between $15^{\circ} \mathrm{C}$ and $30^{\circ} \mathrm{C}$ and relative humidity of $75 \%$ ). Small ruminants are enclosed during the night while allowed to graze and browse during the day under the supervision of young boys. The seasonal characteristics of the area are summer (June - September) autumn (October - November), winter (December February) spring (March - May).

The present study was conducted based on data collected through a questionnaire on farms raising sheep \& goat with crops in mixed farming. The study was conducted on 99 randomly selected sheep and goat farms in four (Matruh, El-Nigila, Sidi-Barani and El-Dabaa) out of seven districts in Matruh Governorate.

The sheep and goat farms were classified into four groups according to small ruminant holding; $\leq 100$ animals (33 Farms), $>100$ to $\leq 200$ animals (30 farms), $>200$ to $\leq 300$ animals (23 farms) and $>300$ animals (13 farms). The sample was considered representative of the number of farms in each category that were found in agricultural administration records.

The studied farms were selected to represent the common sheep and goat farms operated as mixed farming system, where both animals raising and crop cultivation activities are practiced. The data on farms were collected during December 2008 to April 2009.

The questionnaire was developed and pre-tested on a limited number of farms with good experience in sheep and goat practices. Data collected included average crop areas, farm size, average milk production of sheep and goat in farms and some reproductive parameters (lambing / kidding interval, age at first lambing/kidding, lactation length, and season of mating) number of services for conception, most common diseases, and animals marketing. Data were analyzed using SAS for 
Windows (1998). Two models were used to study different factors affecting milk production and grazing areas: Model I was used to evaluate factors affecting milk production such flock size, lactation length, parity number, kidding interval, age at first kidding and season of mating. Model II was used to test impact of flock size, farm size, on grazing areas /farm. Details of these models are shown below:

\section{Model I}

$\mathrm{Y}_{\mathrm{ijklmo}}=\mu+\mathrm{F}_{\mathrm{i}}+\mathrm{L}_{\mathrm{j}}+\mathrm{P}_{\mathrm{k}}+\mathrm{K}_{\mathrm{l}}+\mathrm{A}_{\mathrm{m}}+\mathrm{S}_{\mathrm{n}}+\mathrm{e}_{\mathrm{ijklmno}}$

Where

$\mathrm{Y}_{\mathrm{ijklmno}}=$ milk yield;

$\mu=$ overall mean;

$F_{i}=$ the effect of flock size, $i=1,2,3$ and 4 ;

$\mathrm{L}_{\mathrm{j}}=$ the effect of length of lactation $\mathrm{i}=2,3,4$ and 5 months

$\mathrm{P}_{\mathrm{k}}=$ the effect of parity No. $=4,5,6$ and 7

$\mathrm{K}_{1}=$ the effect of kidding interval, $\mathrm{j}=8,9,10,11$ and 12 months

$\mathrm{A}_{\mathrm{m}}=$ the effect of age at fist kidding, $\mathrm{k}=12-14,15-17$ and 18- 20 months;

$\mathrm{S}_{\mathrm{n}}=$ the effect of season of mating, $1=$ winter $2=$ summer

$\mathrm{e}_{\mathrm{ijkmno}}=$ the residual effect

\section{Model II}

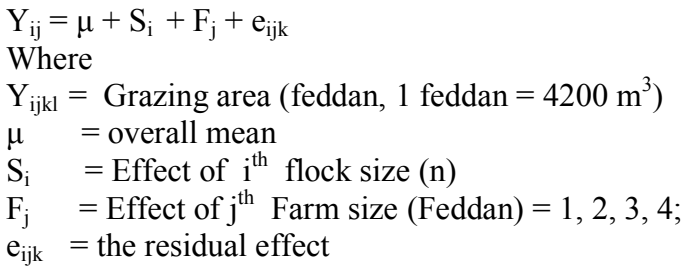

\section{RESULTS AND DISCUSSION}

Results for milk yield per group size, lactation length, parity number, kidding interval, age at first parturition and season of mating are shown in Table 1. There was no significant effect $(\mathrm{P}<0.05)$ for group size on average daily milk yield $(\mathrm{ADM})$ for sheep and goat. This result could be due to that fact the farms in the area use the same feed resources and sheep and goat rearing system with traditional methods regardless of flock sizes. Productive parameters showed that lactation length significantly differed $(\mathrm{P}<0.05)$ among the four sizes on $(\mathrm{ADM})$ for ewes. The ADM of ewes had milk duration of 2 months which was significantly $(\mathrm{P}<0.05)$ less in than those milked for 3 and 4 months. The same trend for ewes milked 3 months which was significantly $(\mathrm{P}<0.05)$ less in ADM than those milked 4 months. These results might be attributed to better management and good feeding or arrangement round lambing season. For does, lactation length significantly $(\mathrm{P}<0.05)$ affected ADM, with ADM for does milking 2 months significantly $(\mathrm{P}<0.05)$ lower than those milked for 3,4 or 5 months Does milking 3 or 4 months have no significant differences $(\mathrm{P}<0.05)$ between each other. However, significant difference $(\mathrm{P}<0.05)$ in ADM was found between does milking 3 or 4 months and those lactating 5 months. 
Table 1. Least squares means (LSM) and standard error (SE) for milk yield per flock size, lactation length, parity number, kidding interval, age at firs kidding and seasons of mating

\begin{tabular}{|c|c|c|c|c|c|c|}
\hline \multirow{3}{*}{ Effects } & \multicolumn{3}{|c|}{ Sheep } & \multicolumn{3}{|c|}{ Goat } \\
\hline & \multirow[t]{2}{*}{$\begin{array}{l}\text { No. of } \\
\text { farms }\end{array}$} & \multicolumn{2}{|c|}{$\begin{array}{l}\text { Av. Milk yield } \\
\text { per day (liter) }\end{array}$} & \multirow[t]{2}{*}{$\begin{array}{l}\text { No. of } \\
\text { farms }\end{array}$} & \multicolumn{2}{|c|}{$\begin{array}{l}\text { Av. milk yield } \\
\text { per day (liter) }\end{array}$} \\
\hline & & LSM & $\pm \mathbf{S E}$ & & LSM & $\pm \mathrm{SE}$ \\
\hline Overall mean & 44 &. .49 & A.Or & 61 &..$\leqslant 0$ & 7. $\varepsilon$. \\
\hline \multicolumn{7}{|l|}{ Flock size } \\
\hline$\leq 100$ & 8 & $\cdot . \leqslant 1$ & $\because \cdot r$ & 14 & 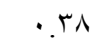 & 0.03 \\
\hline$>100-\leq 200$ & 10 & $\cdot . \leqslant 1$ & $\because r$ & 18 & $\cdot \varepsilon r$ & $\because r$ \\
\hline$>200-\leq 300$ & 13 & 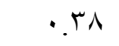 & $\because \cdot r$ & 17 & $\cdot \varepsilon r$ & $\because \varepsilon$ \\
\hline$>300$ & 8 & $\cdot . \leqslant r$ & $\because \cdot r$ & 12 & $\cdot . \leqslant 9$ & $\because \cdot \varepsilon$ \\
\hline \multicolumn{7}{|c|}{$\begin{array}{l}\text { Lactation length in } \\
\text { months }\end{array}$} \\
\hline 2 & 21 & $0.26^{\mathrm{c}}$ & $\because \cdot r$ & 9 & $0.34^{\mathrm{b}}$ & 0.05 \\
\hline r & 11 & $0.38^{b}$ & $\because r$ & rT & $0.41^{\mathrm{ab}}$ & $\because \cdot r$ \\
\hline$\varepsilon$ & 0 & $0.58^{\mathrm{a}}$ & $\because \varepsilon$ & 7 & $0.45^{\mathrm{ab}}$ & $\because 0$ \\
\hline 5 & - & - & & $r$. & $0.52^{\mathrm{a}}$ & $\because \cdot r$ \\
\hline \multicolumn{7}{|l|}{ Parity No. } \\
\hline 3 & 11 & $0.41^{\mathrm{a}}$ & 0.04 & 12 & $0.47^{\mathrm{a}}$ & $\because \varepsilon$ \\
\hline$\varepsilon$ & ir & $0.41^{\mathrm{a}}$ & 0.02 & 11 & $0.42^{\mathrm{a}}$ & 0.04 \\
\hline 0 & 9 & $0.36^{\mathrm{b}}$ & 0.03 & ir & $0.45^{\mathrm{a}}$ & 0.04 \\
\hline 7 & ir & $0.40^{\mathrm{ab}}$ & $\because r$ & 11 & $0.41^{\mathrm{a}}$ & 0.04 \\
\hline V & - & - & 0.03 & 10 & $0.41^{\mathrm{a}}$ & 0.04 \\
\hline \multicolumn{7}{|c|}{$\begin{array}{l}\text { Lambing/kidding } \\
\text { interval (months) }\end{array}$} \\
\hline$\wedge$ & - & - & - & 1. & $0.37^{b}$ & $\because \varepsilon$ \\
\hline 9 & rt & $0.43^{\mathrm{ab}}$ & $\because r$ & $r$. & $0.54^{\mathrm{a}}$ & $\because \cdot r$ \\
\hline 1. & 7 & $0.39^{\mathrm{ab}}$ & $\because r$ & V & $0.41^{\mathrm{b}}$ & $\because .0$ \\
\hline 11 & $\varepsilon$ & $0.36^{\mathrm{b}}$ & $\because \varepsilon$ & - & - & - \\
\hline ir & 11 & $0.45^{\mathrm{a}}$ & $\because \cdot r$ & $r \leqslant$ & $0.41^{b}$ & $\because \cdot r$ \\
\hline \multicolumn{7}{|l|}{$\begin{array}{l}\text { Age at first } \\
\text { parturition } \\
\text { (months) }\end{array}$} \\
\hline $12-14$ & 7 & $0.41^{\mathrm{a}}$ & 0.04 & iv & $0.39^{b}$ & $\because r$ \\
\hline $15-17$ & Ir & $0.41^{\mathrm{a}}$ & $\because r$ & 19 & $0.47^{\mathrm{a}}$ & $\because r$ \\
\hline $18-20$ & $r \leq$ & $0.40^{\mathrm{a}}$ & $\because \cdot r$ & ro & $0.43^{\mathrm{a}}$ & $\because r$ \\
\hline \multicolumn{7}{|c|}{ Season of mating } \\
\hline Winter & YI & $0.41^{\mathrm{a}}$ & $\because \cdot r$ & rv & $0.38^{\mathrm{b}}$ & $\because r$ \\
\hline Summer & rt & $0.39^{\mathrm{a}}$ & $\because r$ & $r \leq$ & $0.48^{\mathrm{a}}$ & $\because r$ \\
\hline
\end{tabular}

These results could be attributed to the better management and good feeding system or better arrangement of kidding or partly genetic differences. These results agree with Hamed et al. (2009) and Caricella et al. (2008) who found that season and year of kidding affected significantly $(\mathrm{P}<0.0001)$ total milk yield. Means of the total 
milk yield were higher $(\mathrm{P}<0.05)$ in spring season $($ March) compared with winter season (October). Parity number showed no significant $(\mathrm{P}<0.05)$ effect on ADM for ewes and does except ewes in fifth parity which had significantly $(\mathrm{P}<0.05)$ lower $\mathrm{ADM}$ values than ewes in other parities. However, ewes in the third, fourth and six parities had no significant $(\mathrm{P}<0.05)$ differences between each other in ADM. Hamed, et al. (2009) reported that total milk yield was significantly $(\mathrm{P}<0.0001)$ affected by parity. Total milk yield increased gradually with the increase of parity until fourth parity. The same authors found that litter size was highly significantly $(\mathrm{P}<0.0001)$ affecting total milk yield which agree with the present results showing that does with multiple kids produced more milk.

Lambing intervals ranged between 9 and 12 months for ewes for the four flock sizes. There are no significant $(\mathrm{P}<0.05)$ differences in $\mathrm{ADM}$ among ewes in all lambing intervals. The only significant difference $(\mathrm{P}<0.05)$ was that between ewes with lambing interval of 11 and 12 months. Whereas, does that had kidding interval of 9 months showed significantly $(\mathrm{P}<0.05)$ highest ADM compared to other does of different kidding intervals. While, does had kidding interval of 8, 10 and 12 months showed no significant differences in ADM. Average daily milk tended to be higher with 12 month lambing interval and 9 months kidding interval for ewes and does, respectively, which might be attributed to a better body condition recovery in 12 months for ewes and 9 months for does.

Age at first lambing, for ewes, did not significantly $(\mathrm{P}<0.05)$ affect ADM. However, does of first kidding at $12-14$ months significantly $(\mathrm{P}<0.05)$ had less ADM than does of first kidding at 15-17 months or 18-20 months. Meanwhile, does kidding at 15-17 and 18-20 months had no significant differences between themselves in ADM. Mamabolo and Webb (2005) found that the age at first kidding was between 16 and 18 months for a survey on goat production in South Africa had better milk production than others goats.

Season of mating, and consequently of kidding or lambing, did not have significantly effect on ADM for ewes but had a significantly effect on does $(\mathrm{P}<0.05)$. This is expected as milk yield is relatively higher in goat which makes it more sensitive for climate and feeding availability.

Table 2 showed least squares means for grazing/ fallow areas as affected by flock size and farm size. The present results showed that there were numerical but no statistical differences $(\mathrm{P}<0.05)$ in grazing /fallow areas for four flock sizes.

Concerning the effect of farm size on grazing area, the farms $\leq 100$ feddan had less grazing/fallow areas than those that have $>100$ feddan. The present results agree with (Khalil et al., 2008) who reported that the affect of farm size on cultivated green forage area was highly significant $(\mathrm{P}<0.05)$ between three farm size $\leq 10,>10-\leq 20$ feddan and $>20$ feddan in Upper Egypt. 
Table 2. Least squares means (LSM) ( \pm SE) for grazing areas as affected by flock size and farm size

\begin{tabular}{lccc}
\hline Effects & No. of farms & \multicolumn{2}{c}{$\begin{array}{c}\text { Grazing areas per } \\
\text { feddan }\end{array}$} \\
\hline & 78 & LSM & \pm SE \\
Overall mean & & 15.56 & 46.67 \\
Flock size (animals) & 32 & 50.77 & 8.08 \\
$\leq 100$ & 24 & 45.50 & $\wedge .71$ \\
$>100 .-\leq 200$ & 15 & 58.27 & 9.21 \\
$>200-\leq 300$ & 7 & 78.21 & $1 \% . \Sigma$ \\
$>300$ & & & \\
Farm size & $1 \leq$ & $\leq \wedge .71$ & $0 . \wedge 0$ \\
$\leq 100$ Feddan & $1 \leq$ & 67.69 & 9.09 \\
$>100$ Feddan & & &
\end{tabular}

Results in Table 3 show average number of flocks/herds, milk production, reproduction parameters for sheep and goat according to flock sizes. Average number of sheep was more than double the goats. This might be due to the fact that goats are kept according to family needs of milk and to some extent, mutton whereas sheep are kept as investment. Sheep and goat males are sold at an average of 23 and 21 months with average body weights of 35 and $23 \mathrm{~kg}$ for sheep and goats, respectively. However, females represent almost two third or more of the flock sizes of the four flock sizes. This might be attributed to the fact that males are sold as soon as they reach the selling weight and females are retained and bred for more than a season.

\section{Average Daily Milk (ADM):}

Average daily milk (ADM) for ewes and does were obtained based on information gathered from the Producers. The ADM for ewes ranged between 0.34 to $0.42 \mathrm{~kg} /$ day and for does was 0.43 to $0.48 \mathrm{~kg}$ /day. These results are agreed with Mehmet et al., 2008 who reported that the average daily milk for goats in four districts in Turkey were $0.30,1.04,0.26$ and $0.58 \mathrm{~kg}$.

\section{Lactation length:}

Lactation lengths were 83.4, 87.0, 81.9 and 81.1 days for ewes and 108.9, 108.9, 111.9 and 83.7 days for does in the four flock sizes, respectively. Suckling period ranged from 1 to 3 months according to availability of feed and body condition of the ewes and does.. These results agree with that found by Mehmet et al. (2008) that lactation lengths were 99.3, 173.0, 98.5 and 172.5 days for goat in four districts in Turkey.

\section{Average parturition intervals:}

Average parturition intervals in months were 10.18, 10.04, 9.67 and 10.54 for ewes and 9.67, 10.20, 10.06 and 10.08 for does. There were no significant differences in parturitions intervals between flock sizes. This may be due to the similarity in climate conditions, the same managements and genetic source of the animals. Also it might be reflection to that all sheep in the region attain their feeds mainly through concentrate supplement with less feed from grazing which is narrowly differ among sectors. In the same time, it highlights that Producer keen to maintain sheep in good 
feeding condition. Moreover, it is recognized that small holders mostly share together in guiding their flocks to graze. Also this situation is expected in traditional management systems where rams and bucks run continuously with ewes and does. The present results are higher than that found by Odubute et al., 1992 who estimated kidding interval by 258 days for Dwarf goats in West Africa

\section{Age at first parturition:}

The ages at first parturition were $17.78,16.92$, and 17.33 and 16.55 months for ewes and 16.6, 16.7, 16.2 and 16.2 months for does in the four flock sizes, respectively. There were no significant differences $(\mathrm{P}<0.05)$ between flock sizes in age at first parturition. These estimates agree with those published by FAO (2002) that age at first lambing ranges between 16.2 and 16.9 months and at first kidding from 13.5 to 17.5 months in mixed farming systems of sub Sahara African countries. However, Mehmet et al., 2008 estimated age at first mating for four districts between 12.8 and 14.3 months for goats in Turkey. Tropical goats have been reported to be polyestrous all year round (Amoah et al., 1996).

\section{Rams and bucks to ewes and does ratio:}

Ram to ewe ratios were $1: 10,1: 13,1: 17$ and $1: 19$ for the four flock/herd sizes, respectively while buck to doe ratios were $1: 8,1: 12,1: 19$ and $1: 12$, respectively. It can be observed that sire ratios were relatively high $(\mathrm{P}<0.05)$ compared to flocks kept in farms or under intensive systems. These results are agreed with Mehmet et al., 2008 who observed that buck to doe ratio in four districts in Turkey were 1:22, 1:17, $1: 26$ and $1: 18$.

\section{Mortality rate:}

Mortality rate within the four flock sizes were 3.6, 0.90, 1.30 and $0.30 \%$ for sheep and $20.60,11.40,8.10$ and $9.00 \%$ for goats, respectively. Main causes of mortality were diseases, severe feed deficiency and/or poisonous with local botanicals. A report of farm-Africa's (1996) stated that diseases were responsible for 19.8\% of goat losses in Keffa. Ketema (2007) reported mortality rate of goats (25.3\%) and sheep (21.7\%) which more comparable to the report of ILCA's (1990) that mortality rates ranged between 25 and $35 \%$ for African sheep and goats. Webb and Mamabolo (2004) reported a wide range of mortality rates in goats (3.8 and $40.1 \%$ ) in Mpumalanga, South Africa.

\section{Litter size:}

Rate of multiple birth was 5.90, 4.40, 5.90 and $9.50 \%$ for sheep and 33.20, 28.60, 28.50 and $43.70 \%$ for does, respectively in the four groups. The higher frequency of twinning estimated for sheep and goat flocks ( $>300$ heads) might be due to the efficient breeding and selection scheme applied and improved management and feeding facilities. Reports and studies over the world gave different estimates for twinning rate as $142.5 \%$ for sheep and $146.5 \%$ for goat, $65-200 \%$ for tropical hairy sheep (Ketema 2007), 87\% in Menz and $81 \%$ in Horro ewes (Mukasa-Mugerwa et al. 2002), between 120.1 and 133.6 for sub-Saharan Africa goat flocks (FAO, 2000) . 
Cultivated areas and their percentage allocated for different crops during winter and summer in the studied areas for the four flock sizes groups are presented in Table 4. The cultivated land in the studied area is not officially owned by producers but they cultivate the land for their livelihood is the practice of producers in most Egyptian deserts. Producers with larger flock/herds size $>300$ heads have large farm holdings (164.17 Feddan.). those with medium flock size $>100-\leq 200$ and $>200-\leq 300$ hold land range between 100 and 120 Feddan while the lower flock size hold the lowest farm size (85.82 Feddan).

Table 4. Average cultivated areas, standard error, the relative importance of each crop and grazing areas according to different flock sizes

\begin{tabular}{|c|c|c|c|c|c|c|c|c|}
\hline \multirow[t]{2}{*}{ Crops } & \multicolumn{2}{|l|}{$\leq 100$} & \multicolumn{2}{|c|}{$>100-\leq 200$} & \multicolumn{2}{|c|}{$>200-\leq 300$} & \multicolumn{2}{|c|}{$>300$} \\
\hline & Feddan & $\%$ & Feddan & $\%$ & Feddan & $\%$ & Feddan & $\%$ \\
\hline \multicolumn{9}{|l|}{ A-Winter } \\
\hline 1- Barley & $r .9 \leq \pm 5.62$ & 71 & $\{\wedge .11 \pm 8.1$ & 07 & $7.0 \pm 12.01$ & 71 & I.r. $0 \pm 31.0$ & $V \varepsilon$ \\
\hline 2- Wheat & $V . r \cdot \pm 1.54$ & IT & $1 r .9 r \pm 3.1$ & 17 & $11 . \varepsilon \cdot \pm 2.8$ & IT & $1 Y .0 \cdot \pm 7.50$ & 9 \\
\hline B-Summer & & & & & & & & \\
\hline Watermelon & $r .9 \cdot \pm 0.87$ & 0 & V.r $\Psi 2.85$ & 9 & $r . r \Psi \pm 0.67$ & r & r. $\cdots \pm 0.0$ & r \\
\hline \multicolumn{9}{|l|}{ Fruit trees: } \\
\hline 1- Olive & $0 . \mu 1 \pm 1.39$ & 1. & $\vee . .0 \pm 2.12$ & $\wedge$ & $\vee .09 \pm 1.87$ & $\wedge$ & ^. $\vee \diamond \pm 2.62$ & V \\
\hline 2-Fig & ᄀ. $\cdot 7 \pm 0.99$ & 11 & 9. $T V_{ \pm} 2.41$ & 11 & $9 . \leqslant r \pm 1.20$ & 1. & $11 . r \cdot \pm 3.0$ & $\wedge$ \\
\hline $\begin{array}{l}\text { Unplanted } \\
\text { (Grazing/ } \\
\text { fallow areas) }\end{array}$ & T1. $\leqslant 1$ & rv & 17.91 & $1 \varepsilon$ & Tr.rT & 19 & r.. & 17 \\
\hline Planted areas & $0 \leqslant \leqslant 1$ & 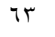 & $17 . \cdot 9$ & 17 & qV.rT & $\wedge$ & $1 \% \mu_{.} .0$ & $\Lambda \varepsilon$ \\
\hline Total areas & No.Ar & $1 \ldots$ & $1 \ldots \ldots$ & $1 \ldots$ & $M \cdot .$. & $1 \ldots$ & $17 \varepsilon .18$ & $1 \ldots$ \\
\hline
\end{tabular}

The flock size increased as according to the available cultivated land. Nevertheless the percentage of unplanted areas had opposing trend, i.e. the flock size decreased as unplanted land increased. This might be due to that there was no need for this land to cultivate in case it had not been raining for growing plants for animals feeding.

The study time was during the rainy season but the rain was very little and as a result, requirements of animal feeding were met from concentrate mixtures and crop by-products. These results are agreed with Khalil et al. (2008) who reported a positive relationship between cultivated area and number of AU/farm.

Non cultivated areas grazing/fallow areas were 31.41, 13.91, 22.33 and 26.12 feddan for the four flock sizes, respectively. These areas depend only on rainfall so it could be noticed that small farm sizes leave more than half the areas unplanted. While the medium and large farm sizes have the capability to cultivate more crops even with little rainfall it might be because they need more crops by-products for animal feeding.

Barley is the main winter crop in the area and represents $56-74 \%$ of the total area. Sheep and goat owners depend on barley in feeding animals or as a source of cash to purchase feeds. Wheat is the second winter crop cultivated in the rangeland (between 9 to $16 \%$ according of available areas) which is used mainly for human consumption over the year. Watermelon is a summer vegetable found in small areas ( $2-9 \%$ of all farm sizes). The watermelon used to cultivate in the region are adapted to drought conditions. Two fruit trees found in the studied areas are olive and fig, the percentage of cultivated areas of both ranged between $15 \%$ for large flock size to 
$21 \%$ for small flock size. The field crop and fruit production in association with sheep and goat production play an important role in risk reduction of farm revenue. Barley and wheat by-products are important for animal feeding while animal's manure is useful to land fertilization.

\section{Sheep and goat marketing:}

Results in Table (5.1) show that producers purchase sources for were mainly from village market $(76-85 \%)$. It might be this marketing source is the best choice as the highest number of animals is available and the selection of good animals would be better. Between $8-11 \%$ of studied farms depend on their own flock/herd for replacement. The purchase from special or small farms is third in rank as it may be for producers who are establishing a new flock/herd or for renewing their flocks. The big traders are the last resort for the purchase of animals it might be because they demand much higher prices compared with the other sources mentioned earlier.

Table 5.1. Sheep and goat purchase sources as percentage of studied farm for four different flock size

\begin{tabular}{llllll}
\hline & $\begin{array}{l}\text { Special } \\
\text { farm }(\%)\end{array}$ & $\begin{array}{l}\text { Own farm } \\
(\%)\end{array}$ & $\begin{array}{l}\text { Large } \\
\text { trader }(\%)\end{array}$ & $\begin{array}{l}\text { Small } \\
\text { trader }(\%)\end{array}$ & Market (\%) \\
\hline$\leq 100$ & $r$ & $\wedge$ & - & $\varepsilon$ & $\wedge$ \\
$>100 \leq 200$ & $\wedge$ & 11 & 1 & $\varepsilon$ & $\vee \tau$ \\
$>200 \leq 300$ & $\varepsilon$ & 11 & 1 & $r$ & $\wedge r$ \\
$>300$ & 0 & 1 & 1 & $r$ & $\wedge r$ \\
\hline
\end{tabular}

Table 5.2 shows that sheep and goat sales in village market or for home consumption represent the main selling channel $(88-96 \%)$. It might be that this market has to be the best choice for most producers because they can get better selling prices. Between $3-10 \%$ of the studied farms consume animals according to family needs or for slaughter on religious occasions. The sale for special or small farms is almost nonexistent except in two farms within small flock sizes. The third ranking for selling animals is to the big trader who the producers exchange animals with feed to defray the cost for feed. The average selling age and weight for sheep and goats are 23 and 21 months and 35 and $23 \mathrm{~kg}$, respectively.

Table 5.2. Sheep and goat sale or home consumption sources as percentage of studied farm for four different flock sizes

\begin{tabular}{lccccc}
\hline & $\begin{array}{c}\text { Special } \\
\text { farm }(\%)\end{array}$ & $\begin{array}{c}\text { Home } \\
\text { consumption }(\%)\end{array}$ & $\begin{array}{c}\text { Large } \\
\text { trader }(\%)\end{array}$ & $\begin{array}{c}\text { Small } \\
\text { trader }(\%)\end{array}$ & $\begin{array}{c}\text { Market } \\
(\%)\end{array}$ \\
\hline$\leq 100$ & $r$ & $r$ & $r$ & - & 97 \\
$>100 \leq 200$ & - & 1 & $r$ & - & $\wedge \wedge$ \\
$>200 \leq 300$ & - & $\wedge$ & - & - & 94 \\
$>300$ & - & $\checkmark$ & $r$ & - & 91 \\
\hline
\end{tabular}

Livestock are generally traded by 'eye-ball' pricing, where weighing is uncommon. Animals are sold on a per-head base and price agreement reached by a long one-on-one bargaining between a seller and a buyer. Under such circumstances, prices paid will reflect buyers' preference for various animal characteristics (weight, 
body conformation, age, health condition, breed and color), the purpose of animals purchased (for resale, slaughter, fattening or breeding), the season of the year (occurrence of religious or cultural festivals) and the bargaining skills of buyers and sellers (Ayele et al., 2003). Marketing of sheep and goats is characterized by strong seasonality and subject to fluctuation. Demand and price increases during festival periods. Factors affecting market supply, as measured by the number offered, include high demand during religious festivals, lambing season, quality and quantity of grazing, as well as cash needs for crop inputs and, later, for food purchase before harvesting (EARO, 2000).

Table (6) shows the most common diseases in studied areas for the four flock sizes. Pulmonary pneumonia which was found in 10 animals in small flock size reduced to 5 for medium size and only two animals for large size. It is apparent that as flock size increased infection with pulmonary pneumonia decreased. This may be attributed to better management in bigger flock size which reduced incidence of the disease. The same trend was found in most diseases except Hemorrhagic septicemia that showed a reverse trend.

Table 6. Most common sheep and goat disease in coastal areas of North West Egypt

\begin{tabular}{|c|c|c|c|c|c|c|c|c|}
\hline \multirow{3}{*}{$\begin{array}{l}\text { Sheep \& Goat } \\
\text { disease }\end{array}$} & \multicolumn{8}{|c|}{ Number of infected animals } \\
\hline & \multicolumn{2}{|c|}{$\leq 100$} & \multicolumn{2}{|c|}{$>100-\leq 200$} & \multicolumn{2}{|c|}{$>200-\leq 300$} & \multicolumn{2}{|c|}{$>\mathbf{3 0 0}$} \\
\hline & sheep & Goat & Sheep & Goat & sheep & Goat & sheep & Goat \\
\hline $\begin{array}{l}\text { Pulmonary } \\
\text { pneumonia }\end{array}$ & 7 & $\varepsilon$ & $r$ & $r$ & $r$ & $r$ & 1 & 1 \\
\hline $\begin{array}{l}\text { Internal \& } \\
\text { external parasites }\end{array}$ & 0 & 0 & v & 0 & $\varepsilon$ & r & r & 1 \\
\hline $\begin{array}{l}\text { Hemorrhagic } \\
\text { septicemia }\end{array}$ & - & $\varepsilon$ & - & v & - & $\wedge$ & 1 & 0 \\
\hline $\begin{array}{l}\text { Foot and mouth } \\
\text { disease }\end{array}$ & 11 & - & 1. & - & $\checkmark$ & - & 0 & - \\
\hline Fasciolasis & 9 & 1 & 11 & r & 7 & $\varepsilon$ & $\varepsilon$ & 0 \\
\hline $\begin{array}{l}\text { Trace elements } \\
\text { deficiency }\end{array}$ & r & 9 & ir & 9 & - & 7 & - & $\varepsilon$ \\
\hline Mange & r & - & $\varepsilon$ & 1 & r & - & 1 & - \\
\hline $\begin{array}{l}\text { Pseudo } \\
\text { tuberculosis }\end{array}$ & - & 0 & r & 0 & 1 & r & - & - \\
\hline Pox & $\varepsilon$ & $\varepsilon$ & r & r & r & r & 1 & 1 \\
\hline Refit valley fever & ir & r & 0 & 1 & r & 1 & 1 & - \\
\hline
\end{tabular}

The wide range of mortality may have been due to managerial differences among households. Producers' impressions are that parasites infestations are a major cause of death. Diarrhea is the main clinical feature of nematode infection in sheep and goats. Diarrhea may also be caused by other pathogens including rotavirus, Escherichia coli or occasionally by Clostridium perfringens coughing and nasal discharges may also be associated with pneumonia or Oestrus ovis infestation. Skin lesions observed are those commonly associated with mange or lice infestation

Traditional and clinical treatments applied for diseases recovery in the study regions are presented in Table 7. Producers in the study area have reasonable 
experience to identify the types of diseases affecting their animals by recognizing the common symptoms. From the description of symptoms, it was obvious that many producers were able to identify diseases such as pulmonary pneumonia, Foot and Mouth Disease, fasciolasis, Mange, Pox and Rift Valley Fever.

Table 7. Traditional and modern veterinary methods adopted by owners of small ruminants in North West Coast region of Egypt.

\begin{tabular}{ll}
\hline Type of treatments given & $\begin{array}{l}\text { Disease or symptom against which } \\
\text { treatment is used }\end{array}$ \\
\hline Garlic & $\begin{array}{l}\text { internal \& external parasites and } \\
\text { Fasciolasis } \\
\text { Waste engine oil or kerosene mixed with }\end{array}$ \\
$\begin{array}{l}\text { Mange, sore mouth, wounds ticks } \\
\text { palm oil }\end{array}$ & Mange \\
$\begin{array}{l}\text { disinfectant } \\
\text { Cleaning }+ \text { sesame seed paste+ caustic }\end{array}$ & $\begin{array}{l}\text { Pox } \\
\text { trace elements deficiency }\end{array}$ \\
$\begin{array}{l}\text { Vaccination } \\
\text { Refit valley fever and Foot and mouth } \\
\text { disease }\end{array}$ \\
$\begin{array}{l}\text { Aspirin, sulpha thiazole or tetra cycline } \\
\text { Pulmonary pneumonia, Hemorrhagic } \\
\text { septicemia and all diseases }\end{array}$ \\
$\begin{array}{l}\text { Caustic }+ \text { salt } \\
\text { Soot mixed with salt }\end{array}$ \\
$\begin{array}{l}\text { Various combinations of plants either } \\
\text { Any illness, especially diarrhea } \\
\text { squeezed and given to the animal to } \\
\text { drink or burned, ground into a powder } \\
\text { and given by mouth }\end{array}$ & Diarrhea and mange \\
\hline
\end{tabular}

Most producers use pharmaceutical drugs from government clinics and open markets. The district had only one governmental veterinary clinic located in the capital of the district which provides animal health services to all farms within the district. The governmental clinic provides veterinary services in two ways; veterinary service at its clinic and special vaccination and treatments of internal and external parasites campaign.

Most producers entirely depend on governmental clinic to vaccinate and treat their animals. The long distance between farms and veterinary clinic compels producers to use traditional animal treatments such as garlic, waste engine oil and kerosene mixed with palm oil, sesame seed paste, herbs, soot mixed with salt and caustic. The Egyptian government disseminates vaccine for epidemic diseases to veterinary units, while for the rest of diseases most reducers use drugs or tradition methods. Important drugs and vaccination services were only provided from the district Office of Agriculture. Most producers reported that lack of veterinarians and inadequate veterinary clinics are major problems in health management. According to respondents, vaccination was provided only when there is an outbreak of disease reported by producers or extension centers. 


\section{CONCLUSION}

From the present study it could concluded that current fertility status of ewes and does is low because usually rams or bucks are left in the flock/herd and may even stay for more than five years, consequently inbreeding occurs. Reproductive performance could probably be improved by controlling breeding. Kidding /lambing is interval is little bit long and can be shortened to be in average of 3 parturitions every 2 years could be ideal for optimum productivity. Many disease problems can be controlled or prevented by proper management. Collaboration between researchers with assistance from extension services can help owners to increase returns from small ruminants.

\section{REFERENCES}

Amoah E.A., S. Gelaye, P. Guthrie and C.E. Rexroad, 1996. Breeding season and aspects of reproduction of female goats. Journal of Animal Science 74: 723- 728.

Ayele S., A. Workalemahu, M.A. Jabbar, M.M. Ahmed and B. Hurissa, 2003. Livestock marketing in Ethiopia: A review of structure, performance and development initiatives. Socio-economics and Policy Research Working Paper 52. ILRI (International Livestock Research Institute), Nairobi, Kenya.

Carnicella D., M. Dario, M.C.C. Ayres, V. Laudadio and C. Dario, 2008. The effect of diet, parity, year and number of kids on milk yield and milk composition in Maltese goat. Small. Rumin. Res., 77: 71-74.

Devendra C. and M. Burns, 1970. Goat production in the tropics. Common wealth agricultural bureaux, Farnham royal bucks. England.

Devendra C. and M. Burns, 1983. Goat Production in the Tropics. Commonwealth Agricultural Bureaux (CAB). Farnham Royal, UK. 184pp.

EARO (Ethiopian Agricultural Research Organization), 2000. National Small Ruminants Research Strategy Document. EARO, Addis Ababa, Ethiopia.

FAO Food and Agriculture Organization of the United Nations, 2002. Cattle and Small Ruminant Production Systems in sub-Saharan Africa - A Systematic Review. Otte, M.J. and Chilonda, P. (eds). Livestock Information Sector Analysis and Policy Branch. FAO, Rome, Italy.

FAO (Food and Agriculture Organization of the United Nations), 2000. Cattle and Small Ruminant Production Systems in sub-Saharan Africa- A Systematic Review. Otte, M.J. and Chilonda, P. (eds). Livestock Information Sector Analysis and Policy Branch. FAO, Rome, Italy.

FARM-Africa, 1996. Goat Types of Ethiopia and Eritrea. Physical description and management systems. Published jointly by FARM-Africa, London, UK and International Livestock Research Institute, Nairobi, Kenya.

Foote W.C., 1991. Reproduction in hair sheep under different climatic conditions. In: Wildeus, S. (Ed.), Proceedings of the Symposium on Hair Sheep Research. Agricultural Experiment Station. University of the Virgin Islands, St. Croix, USA. pp 273-290.

Hamed A., M.M. Mabrouk., I. Shaat and S. Bata, 2009. Estimation of genetic parameters and some nongenetic factors for litter size at birth and weaning and milk yield traits Zaraibi goats. Egyptian Journal of Sheep \& Goat Sciences, Vol. (2), 2009, 55-64. 
Ketema T.K., 2007. production and marketing systems of sheep and goats in Alaba, southern Ethiopia. MSc. thesis University of Hawassa - Ethiopia

Khalil M.A. and M.M.I. El-Ashmawy, 2008. Characterization of dairy farming systems in Upper Egypt. Egyptian journal of animal production. Prod. 45 suppl. Issue Dec. $43-55$ pp.

ILCA (International Livestock Centre for Africa), 1990. Livestock systems research manual. Working Paper 1, Vol. 1. ILCA, Addis Ababa, Ethiopia. 287 pp.

Mamabolo1 MJ and EC Webb 2005. Goat production survey- fundamental aspects to model goat production systems in southern Africa. Case study- agricultural commission - Witfor 2005.

Mehmet k., S.k. Uzun and E. Tuncel, 2008. Characterization of semi-extensive goat production systems in south Marmara region of turkey. J. Biol. Environ. Sci. 2 (5) 53-58.

Mukasa M., E. Anindo, D. Sovani, S. Lahlou-Kassi, A. Tebely, S. Rege, J.E.O. and R.L. Baker, 2002. Reproductive performance and productivity of Menz and Horro sheep lambing in the wet and dry seasons in the highlands of Ethiopia. Small Ruminant Research 45 : 261-271.

Odubute I.K, J.O. Akinokun, and A.A. Ademosun, 1992. Production characteristics of West African dwarf goats under improved management system in the humid tropics of Nigeria. Proc. Intl Workshop, Ile-Ife,Nigeria, pp 202-207.

SAS, 2000. SAS Users Guide, release 6.03 Edition. SAS Institute, Carey, North Carolina USA..

Takele K., G. Duguma, U. Galmessa, S. Abegaz and Y. Gojjam, 2006. Seasonal Changes in Testis Size and Semen Characteristics of Horro Rams. Ethiopian .J. Anim. Prod. 6(1) - 2006: 9-17.

Webb E.C. and M.J. Mamabolo, 2004. Production and reproduction characteristics of South African indigenous goats in communal farming systems. South African Journal of Animal Science 2004, 34 (Supplement 1).

Wilson R.T. 1988a. Small ruminant production systems in tropical Africa. Small Ruminant Research, 1:305-325.

Wilson R.T. 1989b. Reproductive performance of African indigenous small ruminants under various management systems review. Animal Reproduction Sscience, 20:256-286. 
توصيف نُظم إنتاج الأغنام والماعز تحت النظام المزرعى المختلط فى الساحل الثمالي

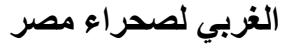

محمد محمد إسماعيل العشماوى، مصطقى عبد الرازق خليل، محمد عبد العزيز الوردانى، صبحى عفيفى محمى

مركز البجوث الزراعية، معهل بحوث الإتتاج الحيواني، الدقي، الجيزة، مصر

تعتبر المجترات الصغيرة جزء متكامل من نظم الإنتاج المختلط (حيو اني- نباتي) فى مصر . يعتبر

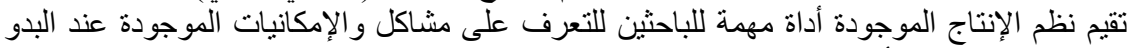

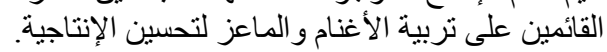

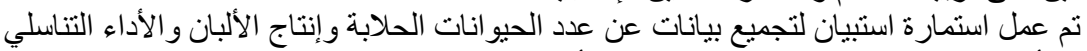

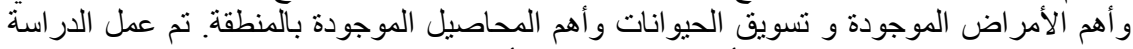

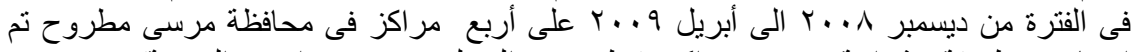

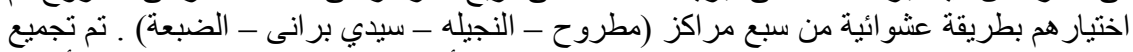

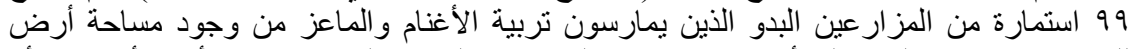

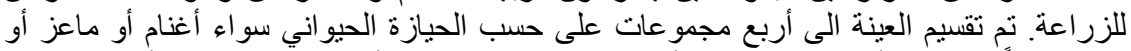

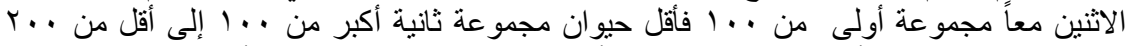

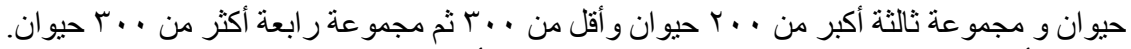

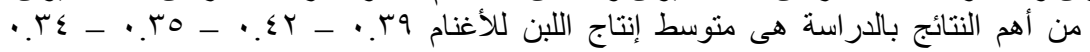

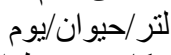

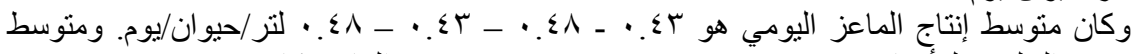

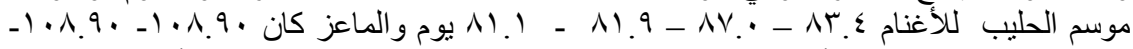

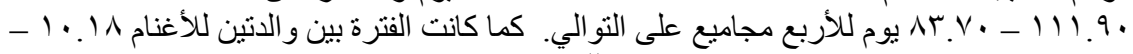

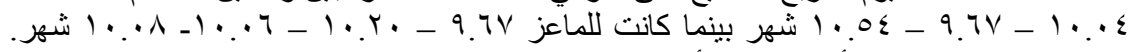

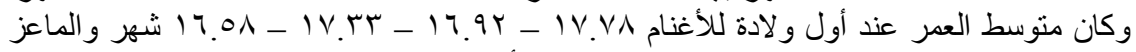

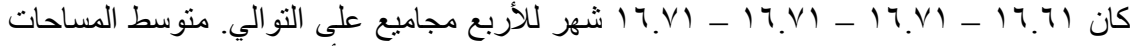

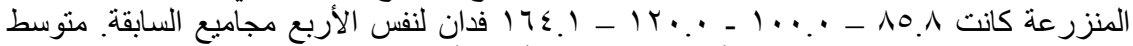

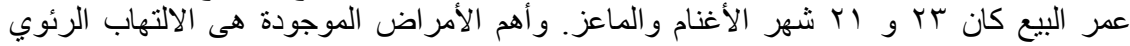

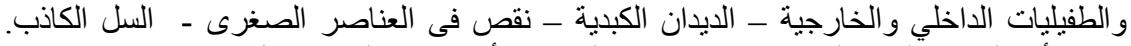

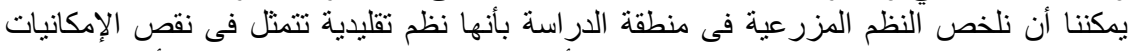

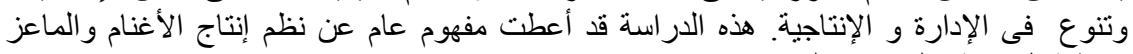

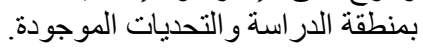


Egyptian J. Anim. Prod. 48, Suppl. Issue, April (2011):181-195

Table 3. Average and standard error for milk production and reproduction parameters of sheep and goat according to flock sizes

\begin{tabular}{|c|c|c|c|c|c|c|c|c|}
\hline & \multicolumn{2}{|c|}{$\leq 100$} & \multicolumn{2}{|c|}{$>100-\leq 200$} & \multicolumn{2}{|c|}{$>200-\leq 300$} & \multicolumn{2}{|c|}{$>300$} \\
\hline & Sheep & Goat & Sheep & Goat & Sheep & Goat & Sheep & Goat \\
\hline Av. No. of sheep and goat /flock & $42.2 \pm 2.87$ & $19.1 \pm 1.52$ & $106.7 \pm 7.34$ & $37.1 \pm 3.71$ & $158.2 \pm 10.99$ & $67.4 \pm 5.82$ & $304.1 \pm 20.93$ & 7r. $8 \pm 6.33$ \\
\hline Av. No. of adult females & $22.4 \pm 2.91$ & $9.9 \pm 1.82$ & $56.2 \pm 5.22$ & $r T . T \pm 3.02$ & $81.9 \pm 11.41$ & 「^. $2 \pm 4.45$ & $148.8 \pm 21.87$ & ห৭. $1 \pm 4.55$ \\
\hline Av. No. of milking females & $1 \leq .0 \pm 3.00$ & १. $\leqslant \pm 2.10$ & ץ. $\wedge \pm 4.81$ & r). $\{ \pm 3.21$ & ᄁ). $\leqslant \pm 12.04$ & $r \leq . \wedge \pm 3.47$ & $V 0 . r \pm 23.65$ & $r r . \pm 3.77$ \\
\hline Milking female $\%$ & 70 & 90 & or & 91 & vo & 70 & 01 & $v_{7}$ \\
\hline Av. Milk production (litter/d) & $0.39 \pm 0.03$ & $\cdot\{r \pm 0.03$ & $\therefore \leqslant Y_{ \pm 0.15}$ & $\cdot .\{\wedge \pm 0.16$ & $\cdot r r_{ \pm} \pm 00$ &..$\leqslant r_{ \pm 1.03}$ & $\cdot r \leqslant \pm 1.04$ & $\cdot\{\wedge \pm 0.97$ \\
\hline Av. Lactation length (days) & $83 \pm 0.23$ & $109 \pm 0.25$ & $87 \pm 0.22$ & $109 \pm 0.24$ & $82 \pm 0.94$ & $112 \pm 0.94$ & $81 \pm 0.90$ & $\wedge 4 \pm 0.88$ \\
\hline $\begin{array}{l}\text { Av. Parturitions interval } \\
\text { (months) }\end{array}$ & $1 \cdot . r \pm 0.22$ & १. $\vee \pm 0.33$ & $1 \cdot . \pm 0.51$ & $1 \cdot . r \pm 0.56$ & १. $\vee \pm 0.92$ & $1 \cdot .1 \pm 0.84$ & $1 \cdot .0^{\circ} \pm 0.75$ & $1 \cdot .1 \pm 0.78$ \\
\hline $\begin{array}{l}\text { Av. age at first parturition } \\
\text { (months) }\end{array}$ & $\vee \vee . \wedge \pm 0.41$ & $17.7 \pm 0.22$ & $17.9 \pm 0.51$ & $17 . \vee \pm 0.55$ & $\vee \vee . r \pm 0.98$ & $17 . r \pm 0.84$ & $17.7 \pm 0.85$ & $17 . \Upsilon \pm 0.78$ \\
\hline No. of rams and bucks in flock & $2.14 \pm 0.21$ & $1.18 \pm 0.07$ & $4.23 \pm 0.43$ & $1.54 \pm 0.21$ & $4.78 \pm 1.00$ & $1.78 \pm 0.96$ & $8.54 \pm 1.03$ & $2.69 \pm 0.98$ \\
\hline Rams /bucks to ewes /does ratio & 1: 10 & 1: 8 & $1: 13$ & $1: 12$ & $1: 17$ & $1: 19$ & $1: 19$ & $1: 12$ \\
\hline No. dead animals last year & $1.0 \cdot \pm 0.53$ & $\Gamma . q \Gamma \pm 0.41$ & 1. $\cdots \pm 0.63$ & $\varepsilon . r \Gamma \pm 0.22$ & ґ. $\cdots \pm 0.67$ & $0 . \leqslant \leqslant \pm 0.71$ & $1 . \cdots \pm 0.79$ & $0.7 V \pm 0.80$ \\
\hline Mortality rate $\%$ & 3.60 & $r \cdot .7$. & 0.90 & $11 . \varepsilon$ & l.r. & 8.10 & 0.30 & 9.00 \\
\hline $\begin{array}{l}\text { No. of animals lambing / kidding } \\
\text { twines }\end{array}$ & $r_{.} \leqslant V_{ \pm 0} 0.40$ & ר. & $\{.70 \pm 0.82$ & $1 \cdot . \pi \mathrm{T} \pm 1.13$ & $9 . \mu 1 \pm 2.18$ & $19.11 \pm 2.12$ & $\langle\wedge . \vee \circ \pm 9.32$ & $r v . \leqslant r \pm 3.75$ \\
\hline $\begin{array}{l}\% \text { of animals lambing/kidding } \\
\text { twins }\end{array}$ & 5.90 & . & 4.40 & 28.60 & 5.90 & 28.50 & 9.50 & 43.70 \\
\hline
\end{tabular}

Mating was natural in all farms

Number of services per conception between 1 to 2 times 
